\title{
Perbandingan DED IPAL Anaerobic Filter dengan Upflow Anaerobic Sludge Blanket untuk Tempat Pelelangan Ikan (TPI) Sedati di Kabupaten Sidoarjo
}

\author{
Rachmat Ridho Permata Putra Siregar, Mas Agus Mardyanto ${ }^{1)}$, dan Mohammad Razif ${ }^{2)}$ \\ Jurusan Teknik Lingkungan, Fakultas Teknik Sipil dan Perencanaan, Institut Teknologi Sepuluh Nopember (ITS) \\ Jl. Arief Rahman Hakim, Surabaya 60111 Indonesia \\ e-mail: razif@its.ac.id ${ }^{2)}$ \\ mardyanto@enviro.its.ac.id ${ }^{1)}$
}

\begin{abstract}
Abstrak-Perencanaan IPAL dilakukan dengan mengidentifikasi karakteristik dan kuantitas limbah dari Tempat Pelelangan Ikan (TPI) di Kabupaten Sidoarjo. Selanjutnya, ditetapkan baku mutu dan kriteria desain. Perhitungan desain meliputi dimensi dan rencana anggaran biaya. Dari hasil perhitungan desain didapatkan desain rinci IPAL sistem Anaerobic Filter meliputi dimensi Bak Ekualisasi (1,2 m x 2,4 m x $2 \mathrm{~m})$, Bak Pengendap kompartemen I (1,2 m x 2 m x $2 \mathrm{~m})$ kompartemen II (0,6 $\mathrm{m} \times 2 \mathrm{~m} \times 2 \mathrm{~m})$, AF tiap kompartemen $(0,80 \mathrm{~m}$ x 1,2 m x 2 m) sebanyak 2 buah. Desain rinci sistem IPAL Upflow Anaerobic Sludge Blanket meliputi dimensi Bak Ekualisasi $(1,2 \mathrm{~m}$ x 2,4 m x 2 m), Bak Pengendap kompartemen I (1,2 m x 2 m x 2 m) kompartemen II (0,6 m x 2 m x 2 m), UASB (1,44 m x 1,6 m x 2,5 m) sebanyak 2 buah. Biaya konstruksi sistem AF sebesar Rp 59.609.889,-. Sedangkan, biaya konstruksi sistem UASB sebesar Rp 50.914.605,-.
\end{abstract}

Kata Kunci- Air limbah TPI, desain anaerobic filter, desain upflow anaerobic sludge blanket, IPAL.

\section{PENDAHULUAN}

$\mathrm{T}$ EMPAT Pelelangan Ikan (TPI) Sedati didirikan sejak tahun 2009, didirikan dan diselenggarakan oleh Koperasi Perikanan terutama di Pulau Jawa, dengan tujuan untuk melindungi nelayan dari permainan harga yang dilakukan oleh tengkulak/pengijon, membantu nelayan mendapatkan harga yang layak dan juga membantu nelayan dalam mengembangkan usahanya. Rendahnya tingkat pemahaman IPAL dan sistem manajemen limbah menyebabkan sulitnya untuk mengelola limbah yang ada, sehingga hampir semua limbah yang dihasilkan di wilayah ini langsung dibuang ke saluran saluran pembuangan air dan langsung menuju ke sungai dan mencemari badan air tersebut. Jika kondisi ini tidak segera diwaspadai, dan permasalahan lingkungan tidak dikontrol secara ketat, maka berbagai dampak negatif akibat kegiatan ini akan semakin besar dan kompleks.

Jumlah debit air limbah pada efluen umumnya berasal dari proses pengolahan dan pencucian. Setiap operasi pengolahan ikan akan menghasilkan cairan dari pemotongan, pencucian, dan pengolahan produk. Cairan ini mengandung darah dan potongan-potongan kecil ikan dan kulit, isi perut, kondensat dari operasi pemasakan, dan air pendinginan dari kondensor.
Kemudian, bagian terbesar kontribusi beban organik pada limbah perikanan berasal dari industri pengalengan dengan beban COD $37,56 \mathrm{~kg} / \mathrm{m}^{3}$, disusul oleh industri pengolahan fillet ikan salmon yang menghasilkan beban limbah $1,46 \mathrm{~kg}$ $\mathrm{COD} / \mathrm{m}^{3}[1]$. Dalam beban cemaran organik yang tinggi terkandung senyawa nitrogen yang tinggi yang merupakan protein larut air setelah mengalami leaching selama pencucian, defrost dan proses pemasakan [2]-[4].

Berdasarkan permasalahan yang ada di TPI Sedati, perlu dilakukan pemeriksaan effluent air limbah pelelangan ikan terhadap badan air sekitar TPI. Dari pemeriksaan ini, maka dapat dilakukan perencanaan untuk membuat teknologi Instalasi Pengolahan Air Limbah (IPAL). Teknologi IPAL yang akan dilakukan pada limbah perikanan adalah berupa proses pemisahan secara mekanik dan pengendapan dalam microscreen baik yang tetap maupun berputar [5].

Utamanya karakteristik limbah cair TPI berupa air limbah yang mengandung lendir dan darah ikan yang keluar dari bakul atau keranjang setelah penyiraman ikan dengan air, serta air limbah hasil pembersihan lantai di TPI. Air limbah tersebut mempunyai nilai BOD serta COD yang tinggi dikarenakan banyaknya zat organik yang terkandung pada limbah cair dari TPI Sedati. Oleh sebab itu, IPAL yang sesuai adalah melalui proses biologis berupa anaerobik proses. Diharapkan dengan adanya perencanaan ini, permasalahan air limbah di TPI dapat diperbaiki sehingga tidak merugikan berbagai pihak, khususnya masyarakat yang tinggal di daerah sekitar TPI Sedati.

\section{METODE DESAIN}

Metode dalam desain ini adalah dengan menghitung dimensi bangunan, menghitung rencana anggaran biaya (RAB) yang dibutuhkan, lalu membandingkan kelebihan dan kekurangan kedua desain IPAL dengan beberapa parameter meliputi luas lahan; efisiensi removal; serta RAB yang dibutuhkan. Desain IPAL dirancang berdasarkan modul DEWATS [6]. Data yang digunakan bersumber dari Tempat Pelelangan Ikan (TPI) Sedati meliputi data penggunaan air bersih bulanan selama satu tahun, serta data sekunder berupa fluktuasi pemakaian air bersih per jam. Pengolahan data meliputi penetapan debit air limbah 
dengan diasumsikan sebesar $70 \%$ dari debit air bersih. Baku muku yang digunakan sebagai acuan effluen adalah Pergub Jatim No. 72 Tahun 2013 tentang Baku Mutu Limbah Cair bagi kegiatan Industri dan Usaha Lainnya [7]. Penggambaran DED (Detail Engineering Design) menggunakan program Autocad 2007. Perhitungan rencana anggaran biaya konstruksi dan operasi didasarkan pada SNI DT-91 series tentang pekerjaan bangunan dan HSPK Kota Surabaya Tahun 2015. Hasil desain dibandingkan kelebihan dan kekurangan masing-masing, selanjutnya ditarik kesimpulan dan saran.

\section{HASIL DAN DISKUSI}

\section{A. Debit dan Kualitas Air Limbah}

Debit air limbah yang digunakan pada penelitian ini diambil dari debit pemakaian air bersih Tempat Pelelangan Ikan (TPI) Sedati di Kabupaten Sidoarjo. Dari hasil perhitungan didapatkan bahwa pemakaian air bersih per hari rata-rata sebesar 3,56 $\mathrm{m}^{3}$ per hari.

Besarnya debit air limbah diasumsikan sebesar $70 \%$ dari debit air bersih. Hal ini dikarenakan sekitar 30\% dari air bersih tersebut digunakan untuk kegiatan operasional lainnya, pembersihan area lahan TPI, serta akibat penguapan. Dari hasil perhitungan diadapatkan debit rata-rata air limbah TPI Sedati sebesar 2,49 $\mathrm{m}^{3}$ per hari atau $0,10 \mathrm{~m}^{3}$ per jam.

Parameter kualitas air limbah yang diukur meliputi BOD, COD, TSS, dan Total N. Dari hasil penelitian pada analisa laboratorium, didapatkan hasil analisa parameter untuk air limbah TPI Sedati bila dibandingkan dengan baku mutu pada tabel 1 .

Tabel 1.

Hasil analisa karakteristik air limbah tempat pelelangan ikan Sedati

\begin{tabular}{ccc}
\hline \hline Parameter & Konsentrasi & Baku mutu \\
\hline BOD & 894 & 100 \\
COD & 1443 & 150 \\
TSS & 280 & 30 \\
TN & 423,9 & 5 \\
\hline \hline
\end{tabular}

Dari data diatas dapat dihitung bahwa efisiensi penyisihan yang dibutuhkan untuk penyisihan BOD sebesar $88,81 \%$ dan penyisihan untuk COD sebesar 89,61\% sehingga effluen yang dihasilkan dapat memenuhi baku mutu yang telah ditetapkan.

\section{B. Penetapan sistem dan kriteria desain IPAL}

Sistem IPAL yang direncanakan adalah sistem Anaerobic Filter (AF) dan sistem Upflow Anaerobic Sludge Blanket (UASB). Masing-masing sistem IPAL dilengkapi dengan unit bak ekualisasi dan bak pengendap. Peran bak ekualisasi adalah sebagai unit stabilisasi debit dan kualitas air limbah sehingga mencegah terjadinya lonjakan hidrolik maupun organik. Dan, fungsi dari bak pengendap adalah sebagai pengendapan awal yang mampu mengendapkan partikel diskrit maupun tersuspensi sehingga mampu mengurangi beban air limbah yang masuk ke unit pengolah biologis. Adapun kriteria desain dari masing-masing sistem IPAL dapat dilihat pada tabel 2 .
Tabel 2.

Kriteria desain sistem IPAL direncanakan

\begin{tabular}{cc}
\hline \hline Anaerobic Filter & Upflow Anaerobic Sludge Blanket \\
\hline HRT di bak pengendap: 2 jam & HRT di bak pengendap: 2 jam \\
HRT di tangki AF: $24-48$ jam & HRT di tangki UASB: $>6$ jam \\
Organic loading: $0,4-5 \mathrm{~kg}$ & Organic loading: $2,5-3,5 \mathrm{~kg}$ \\
COD/m $\mathrm{m}^{3}$ x hari & COD $/ \mathrm{m}^{3} \mathrm{x}$ hari \\
Massa kosong filter: $30-45 \%$ & Tinggi reaktor: $3-5 \mathrm{~m}$ \\
Rasio SS/COD: $0,35-0,45$ & Rasio SS/COD: $0,35-0,45$ \\
\hline \hline
\end{tabular}

C. Perhitungan Dimensi IPAL

1) Dimensi Anaerobic Filter

Perhitungan dimensi Anaerobic Filter didasarkan pada modul DEWATS. Hasil dari perhitungan dapat dilihat pada tabel 3.

Tabel 3.

Dimensi sistem IPAL AF dari hasil perhitungan

Dimensi Bangunan (m)

Parameter

\begin{tabular}{lccc} 
& Bak Ekualisasi & Bnaerobic \\
Panjang & 2,4 & 2 & 1,2 \\
Lebar & 1,2 & 1,2 & 0,8 \\
Kedalaman & 2 & 2 & 2 \\
\hline \hline
\end{tabular}

Jumlah unit tangki Anaerobic Filter yang digunakan sebanyak 2 buah.

2) Dimensi Upflow Anaerobic Sludge Blanket

Perhitungan dimensi Upflow anaerobic sludge blanket didasarkan pada rujukan [8]. Hasil dari perhitungan dapat dilihat pada tabel 4 .

Tabel 4.

Dimensi sistem IPAL UASB dari hasil perhitungan Dimensi Bangunan (m)

Parameter

\begin{tabular}{cccc} 
& Bak Ekualisasi & Bak Pengendap & UASB \\
\hline Panjang & 2,4 & 2 & 1,6 \\
Lebar & 1,2 & 1,2 & 1,44 \\
Kedalaman & 2 & 2 & 3 \\
\hline \hline
\end{tabular}

Jumlah unit UASB yang digunakan sebanyak 2 buah.

\section{Mass Balance}

Perhitungan kesetimbangan massa (mass balance) dibutuhkan untuk mengetahui beban air limbah pada setiap kondisi, baik sebelum maupun sesudah melewati unit IPAL. Pembebanan dilakukan dengan mengalikan debit dengan konsentrasi BOD dan COD. Hasil dari perhitungan mass balance dapat dilihat pada gambar 1 . 

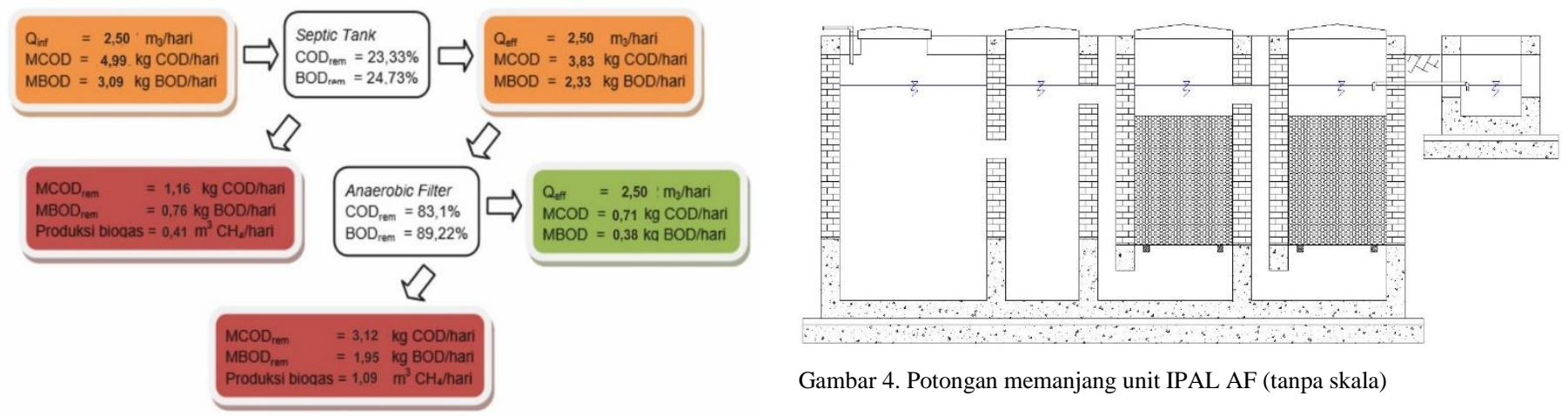

Gambar 4. Potongan memanjang unit IPAL AF (tanpa skala)

Gambar 1. Diagram Mass Balance sistem IPAL AF
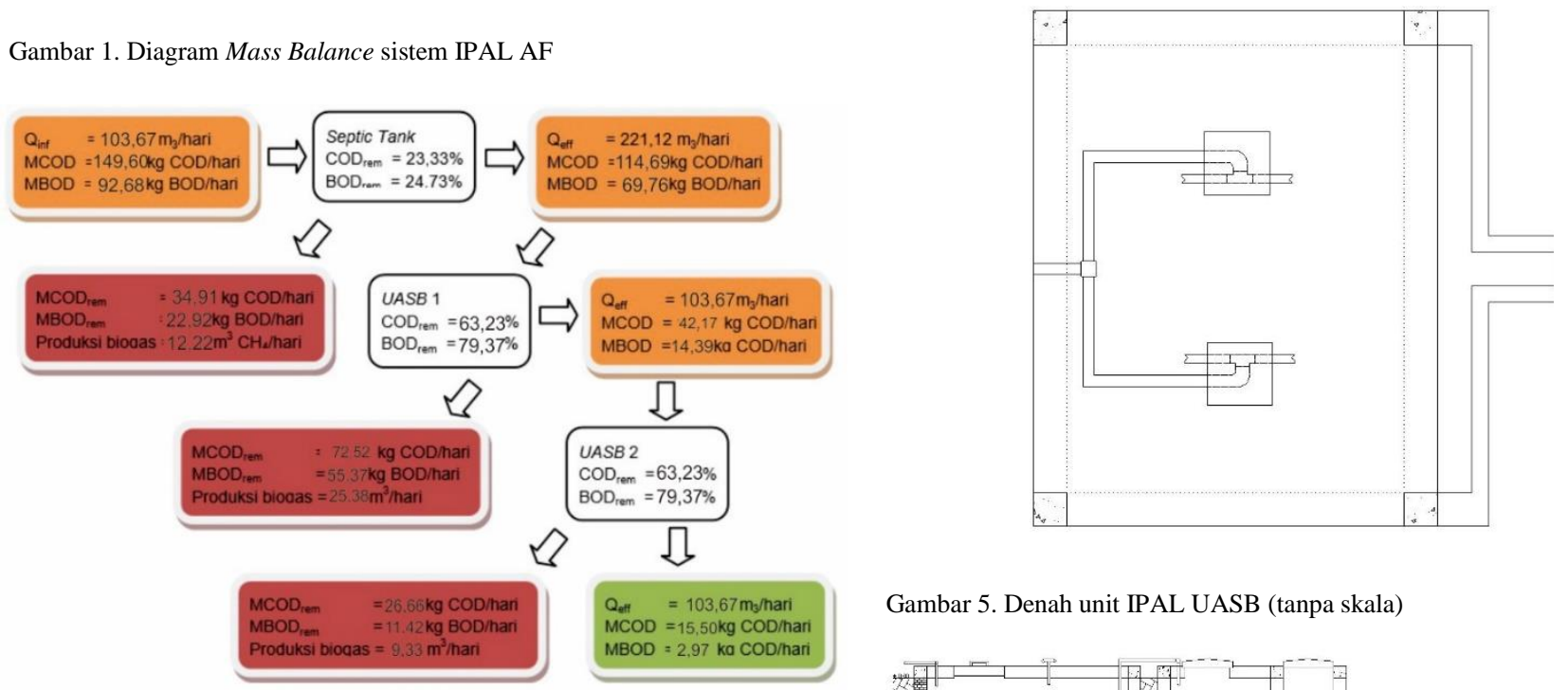

Gambar 2. Diagram Mass Balance sistem IPAL UASB

Perhitungan mass balance ini tidak menggunakan prinsip rasio F/M dikarenakan beban organik sudah distabilkan dalam bak ekualisasi.

\section{E. Gambar Desain Unit IPAL}

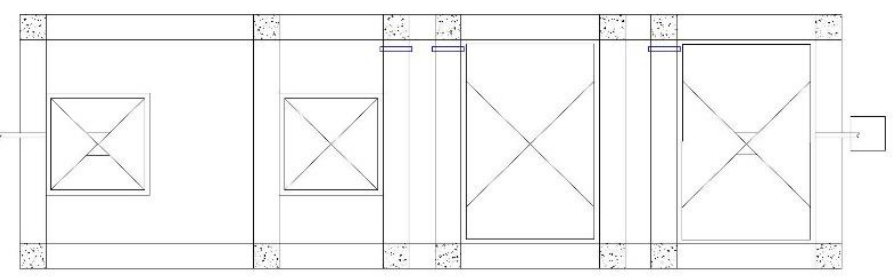

Gambar 3. Denah unit IPAL AF (tanpa skala)

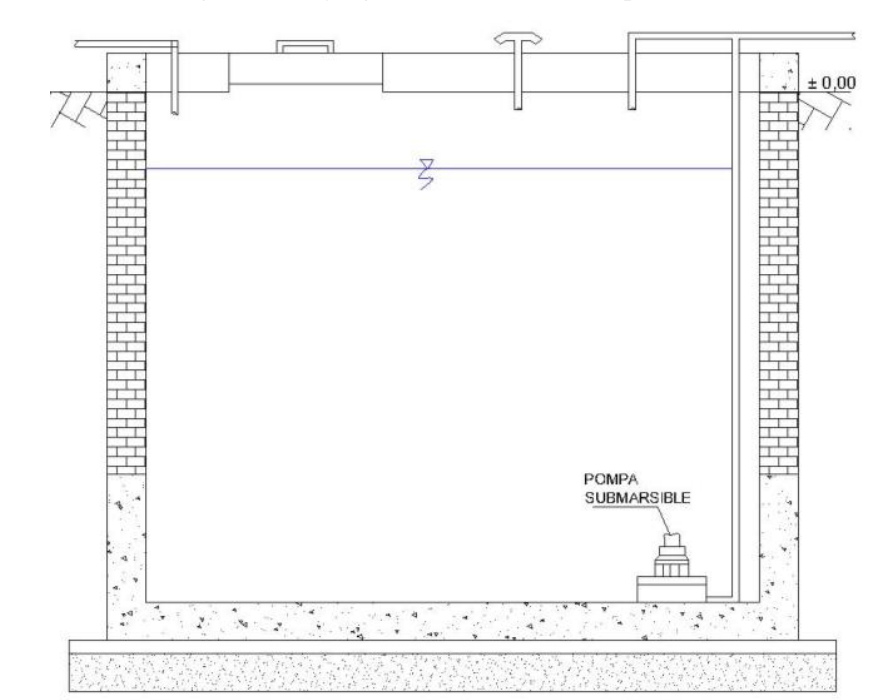

Gambar 6. Potongan Bak Ekualisasi (tanpa skala) 


\section{F. Rencana Anggaran Biaya}

Hasil perhitungan Rencana Anggaran Biaya yang didapat untuk sistem IPAL AF membutuhkan biaya konstruksi sebesar Rp 59.609.889,- dan untuk sistem IPAL UASB membutuhkan biaya konstruksi sebesar Rp 50.914.605,-.

\section{G. Operasi dan Perawatan IPAL Terpilih}

Setelah dilakukan pemilihan IPAL UASB sebagai desain yang paling efektif dan efisien, maka dibuat juga pedoman operasi dan perawatan terhadap unit UASB.

1) Pedoman Operasional

Berikut ini adalah pedoman operasional UASB:

a. BOD,COD, TSS pada influen dan efluen, periksa kinerjanya dan lakukan minimal setiap minggu.

b. Monitor produksi, komposisi dan bau gas dilakukan minimal setiap minggu.

c. pH, VSS, dan kadar air pada bed lumpur melebihi 100 $\mathrm{kg} / \mathrm{m}^{3}$, maka diperlukan permbuangan lumpur dan lakukan minimal setiap minggu.

d. Penanganan lumpur yang dikeluarkan dari dasar UASB dan disalurkan langsung ke unit penanganan lumpur. Dengan drying bed, lumpur dapat dikeringkan selama minimal 6 hari atau bila kadar air sudah mencapai maksimal $70 \%$.

2) Perawatan Unit UASB

Berikut ini adalah pedoman perawatan unit UASB:

a. Lakukan wash-out terhadap lumpur yang mempunyai sifat pengendapan jelek.

b. Jaga kondisi lingkungan di reaktor $(\mathrm{pH}>6,2$, penuhi, nutrien, hilangkan/kurangi senyawa toksik).

c. Sebaiknya tahan bagian lumpur yang berat.

\section{KESIMPULAN/RINGKASAN}

Pada perencanaan ini didapatkan kesimpulan sebagai berikut:

a. Kandungan dari effluent air limbah Tempat Pelelangan Ikan Sedati yaitu, BOD sebesar 894 mg/l, COD 1443 mg/l, TSS $280 \mathrm{mg} / \mathrm{l}$, dan Total $\mathrm{N}$ 423,9 mg/l.

b. Hasil perhitungan desain IPAL anaerobic filter dimensi bak ekualisasi $(1,2 \mathrm{~m} \times 2,4 \mathrm{~m} \times 2 \mathrm{~m})$, bak pengendap kompartemen I (1,2 m x $2 \mathrm{~m}$ x $2 \mathrm{~m})$, kompartemen II ( $0,6 \mathrm{~m}$ x $2 \mathrm{~m}$ x $2 \mathrm{~m})$, AF tiap kompartemen (0,80 m x 1,2 m x $2 \mathrm{~m})$ sebanyak 2 buah dengan presentase removal COD dan BOD total masing-masing sebesar $89,68 \%$ dan $88,95 \%$.

c. Hasil perhitungan desain IPAL Upflow Anaerobic Sludge Blanket menghasikan dimensi bak ekualisasi (1,2 $\mathrm{m}$ x 2,4 $\mathrm{m}$ x $2 \mathrm{~m}$ ), bak pengendap kompartemen I (1,2 $\mathrm{m}$ x $2 \mathrm{~m}$ x $2 \mathrm{~m})$, kompartemen II ( $0,6 \mathrm{~m} \times 2 \mathrm{~m} \times 2 \mathrm{~m})$, UASB tiap unit $(1,44$ $\mathrm{m} \times 1,6 \mathrm{~m} \times 2,5 \mathrm{~m})$ sebanyak 2 buah dengan presentase removal COD dan BOD total masing-masing sebesar $90,24 \%$ dan $97,96 \%$.

d. Rencana Anggaran Biaya Unit AF Rp 59.609.889,-. Sedangkan Unit UASB Rp 50.914.605,--

\section{UCAPAN TERIMA KASIH}

Penulis mengucapkan terima kasih kepada dosen pembimbing, dosen co-pembimbing, dan dosen penguji Tugas Akhir atas saran dan masukan terhadap penulisan jurnal ini.

\section{DAFTAR PUSTAKA}

[1] River, L., Aspe, E., Roeckel, M., dan Marti, M. C. 1998. Evaluation of Clean Technology Process in The Marine Product Processing Industry. J. Chem. Technol. Biotechnol., 73, hal. 217-226.

[2] Battistoni, P., Fava, G., dan Gato, A. 1992. Fish Processing Watewater: Emission Factors and High Load Trickling Filters Evaluation. Wat Sci Tech., 25, hal. 1-8.

[3] Mendez, R., Omil, F., Soto, M., dan Lema, J. M. 1992. Pilot Plant Studies on The Anaerobic Treatment of Different Wastewaters from A Fish Canning Factory. Wat Sci Tech., 25, hal. 37-44.

[4] Veranita, D. 2001. Studi Tentang Karakteristik Limbah Cair Industri Pengolahan Tuna Beku di PT. Indomaguro Tunas Unggul, Jakarta. Skripsi. Jurusan THP FKIP-IPB. Bogor.

[5] Bergheim, A., Seymour, S., Sanni, S., Tyvold, T. dan Fivelstad, S. 1993. Measurements of Oxygen Consumption and Ammonia Excretion pf Atlantic Salmon (Salmo salar L.) in Commercial Scale, Single Pass Freshwater and Seawater Landbased Culture Systems Aquae. Eng., 10, hal. 251-267.

[6] Sasse, L. 1998. DEWATS: Decentralised Wastewater Treatment in Developing Countries. Germany: Bremen Overseas Research and Development Association (BORDA).

[7] Peraturan Gubernur Jawa Timur. 2013. Peraturan Gubernur Jawa Timur. No. 72 Tahun 2013, tentang Baku Mutu Air Limbah Bagi Industri dan/atau Kegiatan Usaha Lainnya, diunduh (http://blh.jatimprov.go.id/index.php?option=com docman\&task=doc do wnload\&gid $=540 \&$ Itemid $=156$ )

[8] Chernicharo, C. A. D. L. 2007. Biological Wastewater Treatment: Anaerobic Reactors. IWA Publishing, 4, hal-202-204. 